\title{
The Role of Banks in Empowering Women Entrepreneurs in Small and Micro Enterprises (SMEs) in Kenya: A Case of Cooperative Bank of Kenya
}

\author{
Fridah Muriungi Mwobobia ${ }^{1}$ \\ ${ }^{1}$ Business \& Globalization Faculty, Limkokwing University of Creative Technology, Gaborone, Botswana \\ Correspondence: Fridah Muriungi Mwobobia (Mrs), Business \& Globalization Faculty, Limkokwing University of \\ Creative Technology, P. O. Box 10313, Gaborone, Botswana. Tel: 267-72-259-682. E-mail: \\ joyfredahmuriungi@yahoo.com
}

Received: February 26, 2013

Accepted: April 26, $2013 \quad$ Online Published: May 12, 2013

doi:10.5430/ijba.v4n3p73

URL: http://dx.doi.org/10.5430/ijba.v4n3p73

\begin{abstract}
The study aimed to establish the role of banks in empowering women entrepreneurs in Small and Micro Enterprises (SMEs) in Umoja market in Nairobi, Kenya- A case of Cooperative Bank of Kenya. The questions explored were i) What role has Cooperative Bank of Kenya (Westlands Branch) played in empowering SMEs owned by women entrepreneurs in Umoja market in Nairobi, Kenya ii) How many small scale women entrepreneurs in Umoja market has Cooperative bank (Westlands Branch) assisted so far iii) In which industry do these small scale women entrepreneurs mainly operate iv) What challenges has Cooperative bank faced in pursuing such endeavours v)What can be recommended to Cooperative bank and other lending institutions in the future. Random sampling approach was applied and 100 women entrepreneurs were picked. Questionnaires and interview methods were used as the main data collecting instruments. Findings revealed that Cooperative bank has helped finance many small scale women entrepreneurs in Umoja market, SMEs in Umoja are mainly sole proprietorships operating businesses such as: salons, food outlets, transport, clothing shops among others, the challenges faced by the bank are mainly: nonpayment, diversion of funds, poor financial management among others. Among the recommendations put forward are: extension of loan repayment period, giving of loans in terms of assets, educating customers on the importance of loan repayment, training women entrepreneurs in areas of finance, budgeting and general management aspects and further research in this field.
\end{abstract}

Keywords: women entrepreneurs, small and micro enterprises (SMEs), empowerment, Cooperative Bank of Kenya

\section{Introduction}

\subsection{Background to Study}

Women entrepreneurs around the world are making a difference. They contribute numerous ideas, a great deal of energy and capital resources to their communities, generate jobs as well as create additional work for suppliers and other spin-off business linkages (Common wealth secretariat, 2002).

Women have been disadvantaged while competing with men in terms of pay, due to their lifestyle requiring them to have babies, nurse them and still work for promotion (Daily nation, 2012). Female entrepreneurs on average make less than their male counterparts, while value added per worker is lower in firms managed by women than those managed by men- in Europe, Asia, Latin America and sub-Saharan Africa (Sunday, 2012).

Banki Moon the secretary general of United Nations was quoted to say 'African countries should make more effort to empower youth and women and give them the responsibilities of driving economic growth and peace' (Xinhua, 2013).

In Kenya about 48 percent of small- and-meduim sized businesses are run by women. (Matende, 2013). The Kenyan government recognizes that women entrepreneurs have not been on an equal footing when it comes to their access to opportunities and assets but it has yet to effectively address the barriers facing women in business (Athanne, 2011). 
Traditionally, banks were unwilling to provide loans to poor entrepreneurs due to perceived risk. Common concerns included the fact that the unbanked were often illiterate, had no collateral, no prior credit history and were not employed by anyone other than themselves (http://gsbapps.stanford.edu/cases/document/E260 pdf).

\subsection{Statement of the Problem}

The research problem is to investigate the role of banks in empowering women entrepreneurs in Small and Micro Enterprises (SMEs) in Kenya. In specific the research will target Cooperative Bank of Kenya - the Westlands branch.

Cooperative Bank of Kenya is a commercial bank in Kenya, and it is one of the largest banks by assets. It is the third largest financial services provider in Kenya by market value, behind Kenya commercial Bank and Barclays Bank of Kenya. Established in 1965 initially as a cooperative society. The Cooperative bank offers many products such as Savings, investments, Debit cards, checking and loans. It has different types of loans such as; Msamaria Women Loan, Coop Kwa Jirani, Biashara Plus Loan, Maziwa Loan, BiZwise SME Loan, Coop asset finance, short term loans, overdrafts, Bonds/guarantees among others (http://www.co-opbank.co.ke/Main-site/Home/personal-Banking/Loans/ Biashara-plus-loan).

Although women constitute 52 percent of the total Kenyan population, majority of them have been excluded from the formal financial services - for example, few have bank accounts, can access loans, money transfer services, etc. The rural women are more disadvantaged than their urban counterparts. The majority of Kenyans will not be able to give a title deed or car log book especially women- but when it comes loan repayment women are the best (http://www.un.org/ecosocdev/geninfo/afrec/bpaper/maineng.htm). Could this be part of the reason why Cooperative bank is helping women entrepreneurs?

Women entrepreneurs often lack information about how to get a loan, lack the necessary collateral to obtain one and /or face discriminatory laws or practices related to finance and credit (Common wealth secretariat, 2002).

Gray (1996) adds that the women's major problem during the start-up is the credit discrimination. A woman is not allowed to open a bank account or own land without her husband's or father cosignatory. Although inheritance laws were revised with the succession Act of 1981, women have rarely inherited land and other property in their own right. This means that they lack title deeds which are still the most commonly used form of security for borrowing money. But how are they surviving in Cooperative bank?

Formal financial support is seen to be too expensive for many women entrepreneurs and hence they treat this as a last resort. (Mwobobia 2012, Stevenson and St-Onge, 2005). The question is how has Cooperative bank twisted this and managed to lure women entrepreneurs?

The Kenyan Government has acknowledged the problem; the president highlighted the need to attract support for small businesses in his launch of the country's anti- poverty and growth plan known as vision 2030. Could Cooperative bank be pursuing president's vision? (http://www.uneca.org/adfvi/documents/ADFVI_Progress_Report_ENG.pdf)

Diamond (2012) adds that private sector has an obligation to be the engine of growth and employment, and banks have a vital role to play in achieving that. Is this what Cooperative bank is doing?

Commercial banks in Kenya have special products for MSEs, in most cases offered along with other normal banking facilities however concerns have been raised as to the conditions of access to them and the cost of money borrowed. For Cooperative bank of Kenya its financial support ranges between KES 15,000 (US 208) to KES 300,000 (US\$ 4, 110) repayable in six months. Other formal banks lending to SMEs are Standard Chartered, Stanbic and Commercial Bank of Africa or offering wholesale credit to the MFIs (Central Bank of Kenya, 2006).

Being the third largest bank in the country has the bank contributed in empowering the small scale women entrepreneurs in Kenya? The study seeks to find out.

\subsubsection{Objectives of the Study}

The purpose of this study is to investigate the role Cooperative bank of Kenya has played in empowering women entrepreneurs in Small and Micro enterprises (SMEs) in Kenya.

Specifically, the objectives of the study are to:

i) To explore the role of Cooperative bank in empowering women entrepreneurs in small and micro enterprises (SMEs) in Kenya in specific the Umoja market in Nairobi

ii) To examine the number of women entrepreneurs in Small and micro enterprises that Cooperative bank (Westlands bank) has helped so far operating in Umoja market 
iii) To identify the industries these small scale women entrepreneurs are operating in

iv) To explore the challenges faced by Cooperative bank in pursuing such endeavours

v) To recommend an appropriate plan for Cooperative bank and other lending institutions to use in future in pursuing such endeavours

\subsubsection{Research Questions}

i) What role has Cooperative Bank of Kenya (Westlands Branch) played in empowering small scale women entrepreneurs in Kenya specifically in Umoja market in Nairobi

ii) How many small scale women entrepreneurs in Umoja market, has Cooperative bank (Westlands Branch) assisted so far

iii) In which industries do these small scale women entrepreneurs mainly operate

iv) What challenges has Cooperative bank faced in pursuing such endeavors.

v) What can be recommended to Cooperative bank and other lending institution in future in pursuing such endeavors

\section{Significance of Study}

The study will highlight the role Cooperative bank has played in empowering small scale women entrepreneurs in Kenya and identify the industries that mostly small scale women entrepreneurs operate in. The study will also highlight the challenges the bank experiences in pursuing such endeavors.

Lessons learnt here will be used to highlight on areas of improvement to Cooperative bank and other lending institutions in Kenya in order to enable them to effectively play their role. The study is a humble contribution to the body of knowledge regarding the financing of SMEs owned by women in Kenya and other third world countries.

\section{Research Methodology}

\subsection{Research Design}

The study adopted a mixture of approaches, incorporating both positivism and phenomenology research paradigms. The triangulation approach was adopted due to the nature of the sample studied. The sample involved bank management and the women entrepreneurs. The use of multiple research methods ensured the reliability and validity of the results.

\subsubsection{Population and Sample}

The population comprised of women entrepreneurs based in Umoja market in Nairobi that has 313 stores. (Kenya Gazette. 2008). A random sampling was done and from 313, hundred women entrepreneurs were picked. This represents about 32 percent which is a representative sample. According to Cooper and Schindler, (2003) a sample of $10 \%$ of the total population can give good reliability under the circumstances. The manager of the Cooperative bank -Westlands Branch was interviewed.

\subsubsection{Instrumentation}

Care was taken to ensure that questionnaire questions were structured in such a way that similar or familiar questions started, followed by orientation, content and personal items were placed at the end and were worded carefully to avoid offending the respondents. The questionnaire consisted of both closed and open-ended questions.

Before administering the questionnaire, the pre-test was done, two senior university researchers were requested to review the questionnaires in order to determine face validity. All their comments were noted and incorporated into the questionnaires. As a rule in sample surveys, a pre-test was carried out in selected entrepreneurs mainly to test the applicability of the questionnaires. The pre-test results were relied on in finalizing the questionnaire. In this way, content validity was ensured. Interview schedule items were pre-tested and necessary amendments were made in order to maximize returns and minimize the error rate.

\subsection{Data Collection}

Data was collected from the women entrepreneurs in Umoja market using questionnaires and the Westlands Cooperative branch bank manager was interviewed. Four research assistants were hired and trained on how to administer the research instruments. The fieldwork was undertaken during the months of July and August 2012.

With regard to scientific validity, the research was carried in a manner that ensured its academic integrity and scientific validity: there was no fabrication or plagiarism. Care was also taken when choosing participants; no force was used. 


\subsection{Data Analysis and Results}

\subsubsection{Data Analysis}

The research design combined the qualitative and quantitative paradigms therefore, data was analyzed qualitatively and quantitatively. Quantitative data from the closed questionnaire items was statistically analyzed and presented using descriptive methods, such as tables for easier crosschecking and comparison with the qualitative data.

The data was initially classified into four categories each representing a means of measuring variables: nominal, ordinal, interval and ratio. The nominal measure involved the descriptive data that indicated alternative states of variables for, example, women entrepreneurs who had received bank loan and those who had not received.

Ordinal measures are ranked estimates usually reflecting either choices made by the subject or categories determined by the researcher for example age range, business units, repayment periods etc.

Interval measures are variables whose attributes can be rank- ordered, for example, loan repayment period while ratio measures are variables based on absolute scale, which has a fixed zero point, for example years in business operation by the women entrepreneurs (Mancosa Research Methods Module 2001).

After data was classified, it was then presented and analyzed in the form of tables, graphs, charts and frequencies:

- Bar graphs were used to show business units, loan repayment periods, age-range, years of operation in business, challenges faced by women in businesses etc

- Trend a line graph was used to show different years when different businesses were started

- Pie charts were drawn to represent proportions such as business types, monetary and any other assistance by the bank, etc. First percentages were calculated and then converted into degrees.

- Tables were used to show the type of assistance received from the bank, suggestions put forward by women entrepreneurs etc

Having drawn the graphs, charts and tables further analysis was done which encompassed describing, interpreting, cross referencing and comparing variables.

Conclusions were drawn from the results, which were generalized to cater for the whole population.

The qualitative data from the interview was de-textualized by converting the extended texts into more manageable forms such as summaries, charts and diagrams. The research applied the deduction position.

\section{Findings and Discussions}

These findings (Figure 1) show that these businesses in Umoja possess the characteristics of small scale businesses which according to Wokorach (1997) sell variety of edibles, vegetables, others are plumbers, hairdressers, painters, farmers, travel agents, food, transport, hotels among others.

Figure 2 reveals that $26 \%$ of these businesses started in 2008, a year after the Cooperative bank introduced the women empowerment package hence making capital available, capital is one of the key factors to start an enterprise. Years, 2011 and 2012 shows a decline in the business start-ups, this could be due to the effects of the world recession.

Concerning the business units, sole proprietorship took the highest percentage (figure 3), this could be, due to the following reasons: it is easier to set up and run, requires less capital and is not complicated because it is run by one person hence decisions can be made quickly. Dransfield and Needham (2001) argues that a sole trader is the common form of business ownership and easiest to set up with little capital requirement which is currently being set by young entrepreneurs. Partnership came second this could be due to the fact that partnerships are also easy to set up and are usually found in shop ownership and professional practices such as doctors, solicitors and dentists. Partnership could be common because it provides division of labour hence owners could end up specialising which could lead to efficiency. Limited companies took a lower percentage possibly because the legal and time consuming process of forming them. According to the companies act two documents have to be prepared before the company is created: Memorandum of association and articles of Association.

As pertains financial assistance (Figure 4) indicated that a bigger portion 75 percent acknowledged reception of the finance from the bank. Every business needs capital to start, expand or modernise. Start up capital is important in that it enables the business to acquire initial assets, to maintain day to day operations, to pay for any new projects and to act as any financial reserve for any unexpected costs (Wokorach 1997). In addition those businesses could have taken loans from Cooperative Bank because this is the main method of financing available. Short- term capital may 
be obtained in form of loan from a building society or a commercial bank. Cooperative bank could be attractive may be because of the low interests. As regards the small portion 25 percent that has not taken any loan from Cooperative bank this could be due to lack of collateral, or simply not meeting the bank's requirements such as not having adequate securities to cover the loan at least 150 percent chattels, house hold goods or business assets. They could also have resorted to other sources of capital such as overdrafts, trade credits, factoring, savings or family support or the famous merry-go-round.

Concerning the type of financial assistance taken from the bank, (Table 1) showed that Nguzo loan is the one which is highly utilized, this could be because it offers small amounts ranging from KES 5000-500,000 which could be manageable by the small-scale women entrepreneurs. Msamaria loans took the second position, this could be because of the longer repayment period and also because it offers a bigger amount which women could be taking to start or expand their businesses. On the other hand other women did not opt for it because it is could be viewed as too expensive hence the last resort (Mwobobia 2012, Stevenson \&st-orange 2005).

As concerns repayment period majority of the women entrepreneurs 25.9 percent went for the longest repayment period which is 36 months (Figure 5). Longer repayment period could be preferred because it gives business time to organize themselves.

Figure 6 shows the women entrepreneurs acknowledging Cooperative bank's financial help to women and 81 percent were positive. The 19 percent that turned out negative could have problems with requirements which the manager cited as having an account, having an operating business or could have experienced auctioning of properties as the bank manager indicated, which they do 90 days upon failure to make monthly payment.

As pertains any other help got from the bank almost half of the women entrepreneurs acknowledged (Figure 7) however it looks like the bank needs to do more on training, mentoring and closer supervision.

Figure 8 indicates that almost 40 percent of the women entrepreneurs are facing the problem with the loan repayment. This could be due to number of factors such as businesses not performing well, recession effects, poor management of finance, failed projects, diversion of funds as the manager indicated. The manager reported the default rate of 5percent. This often happens in businesses. To (Mwobobia 2012, Makokha 2006) women have financial social demands that compete with business capital, leading to diversion of fund away from business needs. Family demands tend to drain the savings and income made by the business.

Financial management and budgeting problem came second this could be due to lack of education especially in finance. This agrees with Athanne (2011) who argues that lower education levels puts women entrepreneurs in Kenya at a disadvantage. Lack of education could be due to time constraint, for when business trainings are available women may not be able to take advantage due to family commitments (common wealth secretariat, 2002). In addition women are less educated than men making them less equipped to manage a business (Bowen, Morara \& Mureithi, 2009).

A bigger percentage (figure 9) shows that the women entrepreneurs are mature people ranging from 30-50+ years. At this age one is mature and capable of being responsible and it is at this stage many people especially women have fully decided what they want to do. Comparative studies show that women start businesses at an older age than men, when they have have had family and children (Mwobobia 2012, Zororo 2011, Green \& Cohen 1995).

From the indications in (Table 2) a bigger percentage 33percent suggested training of women entrepreneurs on money matters, a second biggest percentage felt the bank should improve its customer service. Other suggestions were reduction of interest rate, Increment of repayment period, more support, advise and mentorship to be given to women entrepreneurs, giving loans in form of assets rather than cash, bank to increase its marketing strategies, bank to benchmark with developing countries and removal of interest rates among others.

\section{Conclusion}

From the research findings, the study has established that Cooperative bank has empowered many small scale women entrepreneurs in Umoja market through giving loans, majority of the women entrepreneurs run small businesses with sole proprietorship leading and operating businesses in industries such as hair and beauty, food, transport among others, majority of the businesses have operated for about five years since they started in 2008. The survey established that the bank has funded +1000 women so far.

The bank manager reported the challenges faced as follows: defaulting cases of at least 5 percent, problem with credit follow up, funds diversion, problems with financial management, budgeting among others. The study also established that entrepreneurs in Umoja market are mature people ranging from 30-50+ years. 


\section{Recommendations}

Based on the survey findings the following recommendations are put forward:

- The banks should consider extending the loan repayment periods may be to 48-60 months

- The banks should consider giving loans in terms of assets instead of cash to avoid the temptation of cash misuse and diversion

- The bank should educate customers on the importance of paying loans on time and keeping in constant touch with the bank officers because these are character based loans

- More training should be given to women entrepreneurs in areas of: finance, budgeting, loan repayment and general business management aspects

- The banks should increase their credit officers in order to monitor the borrowers effectively and do the follow up

- The bank should benchmark with banks in the developed countries to get new ideas and ways of doing things that could benefit the local entrepreneurs

\section{Further Research}

Based on the findings of this research, further research is recommended in this area especially on the challenges faced by small scale women entrepreneurs in sourcing business finance.

\section{References}

Acs, Z.J. (1992). Small business economics: A global perspective. Challenge, Nov-Dec.

Athanne. (2011). Entrepreneurship in Kenya, Nairobi.

Bowen, M., Morara, M., \& Mureithi. S. (2009). Management of Business challenges among smalll \& Micro enterprises in Nairobi- Kenya: KCA. Journal of Business Management, 2.

Cooper, D. R., \& Schindler, P. S. (2003). Business Research Methods. New York: McGraw-Hill/Irwin.

Cooper, D. R., \& Schindler, P. S. (2006). Business Research Methods (8th ed). New York: McGraw Hill/Irwin.

Daily Nation. (2012). Survey shows women business graduates earn more than males. Nairobi: Kenya.

Dransfield, R., \& Needham, D. (2001). Business studies for you ( $2^{\text {nd }}$ ed.). United Kingdom: Nelson Thornes Ltd. Delta place.

Kenya Gazzette. (2008). Government printers. Nairobi.

Management College of Southern Africa. (2001). Research Methods. Durban: South Africa.

Masinde, J. (2012). Small \& Medium firms to drive growth. Daily Nation, Tuesday, November 13.

Matende, D. (2013). In the driver's seat: Msafiri Jan-Feb 2013 Edition.

Meru, K.A., \& Struwig, M. (2011). An Evaluation of entrepreneurs' perception of business-Incubation services in Kenya. International journal of Business Administration. http://dx.doi.org/10.5430/ijba.v2n4p112

Michiri, M. (2013). SMEs lead in job creation as 2012 comes to a close. Standard Newspaper Kenya, Tuesday, January $1^{\text {st }}$.

Munjuri, G.M. (2011). A survey of criteria used by commercial banks in Kenya to determine employees to retrench. International journal of Business Administration. http://dx.doi.org/10.5430/ijba.v2n2p57

Mutua, J. M., \& Wasike, S.K.W. (2009). ICT adoption and performance of small-medium-sized Enterprises in Kenya. Special Research project on ICT and Economic Development in Africa.

Mwobobia, F. M. (2012). Role of business management into the success and survival of small businesses. The case of Star Learning Centre in Botswana. International Journal of Business Administration. http://dx.doi.org/10.5430/ijba.v3n1p93

National Baseline Survey. (1999). National Micro and Small Enterprise Baseline Survey. Nairobi: ICEG and K-REP. Njuguna, N. (2012). Keep it in the family: Msafiri Nov-Dec 2012 Edition.

Opiyo, R.O., \& K'Akumu, O. A. (2006). ICT application in the informal sector: The case of the Kariokor market MSE cluster in Nairobi. Urban Forum, 17(3), 241. 
Republic of Kenya. (2006). Economic survey, the Government printer. Nairobi: Survey, Nairobi: Kenya.

Retrieved June 15, 2012, from http//uneca.org/adfvi/documents/ADFVI_Progress_Report_ENG.pdf

Retrieved June 10, 2012, from http//www.un.org/ecosocdev/geninfo/afrec/bpaper/maineng.htm

Retrieved June 6, 2012, from http://gsbapps.stanford.edu/cases/document/E260 pdf

Retrieved

June

7 , 2012,

from http://www.co-opbank.co.ke/Main-site/Home/personal-Banking/Loans/Biashara-plus-loan

Ronge. E., Ndirangu, L., \& Nyangito, H. (2002). Review of government policies for the promotion of Micro and small scale enterprises in Kenya. KIPPRA Discussion paper.

Stevenson L., \& St-Onge. A. (2005). Support for growth -Oriented Women Entrepreneurs in Kenya. International Labour Organization, Geneva.

Stroeken, Jan H.M. (2001). The adoption of IT by SMEs: the Dutch case. Journal of Enterprising Culture, 9(1), 129-152.

Sunday, F. (2012). The missing half in Kenya's corporate boardrooms. Standard on Sunday, $23^{\text {rd }}$ December 2012.

Sunita, K. (2006). Unleashing the Entrepreneurial Potential of Micro and Small Enterprises in Kenya: Some Experiences and Directions: A Thematic Working Paper Prepared for the Commission on Legal Empowerment of the Poor. Presented at UNHABITAT, Nairobi, Kenya.

Tomecko, J., \& Dondo, A. (1992). Improving the potential of small scale and informal sector. Nairobi: K-REP and GTZ.

Wokorach, J.B. (1997). Commerce (4 ${ }^{\text {th }}$ ed.). Botswana: Salama publishers.

Xinhua. (2013). Ban urges Africa to empower Youth, Women. Daily News, Tuesday $29^{\text {th }}$ January2013.

Zororo, M. (2011). Characteristics and Motivation in Female Entrepreneurship. Case of Botswana. University of Botswana Journal.

\section{Appendices}

\subsection{Research Findings}

\section{Introduction}

Seventy seven (77) out of one hundred (100) questionnaires were responded to reflecting a total of $77 \%$ response. The interview feedback was also factored in.

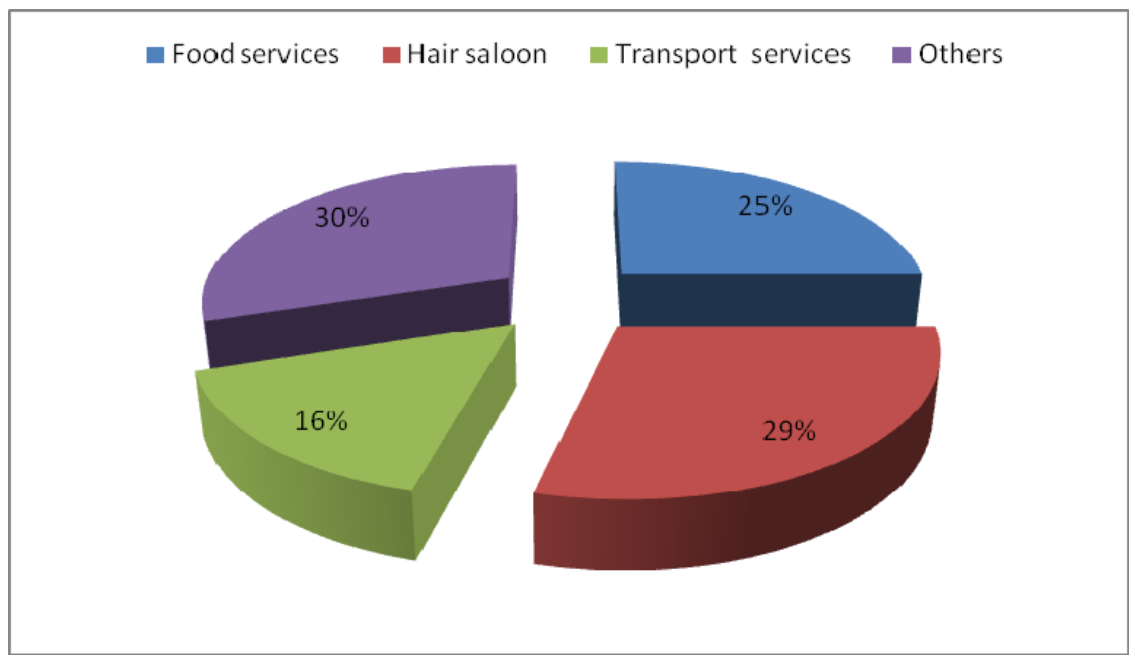

Figure 1. Type of businesses operated by women

Out of 77 respondents, 20 which represents $25 \%$ are in food services, 22 which is $29 \%$ are in Hair saloon, 12 which represents $16 \%$ are in transport and 23 which is $30 \%$ are in other businesses such as interior design, micro-finance, clothing and education. 


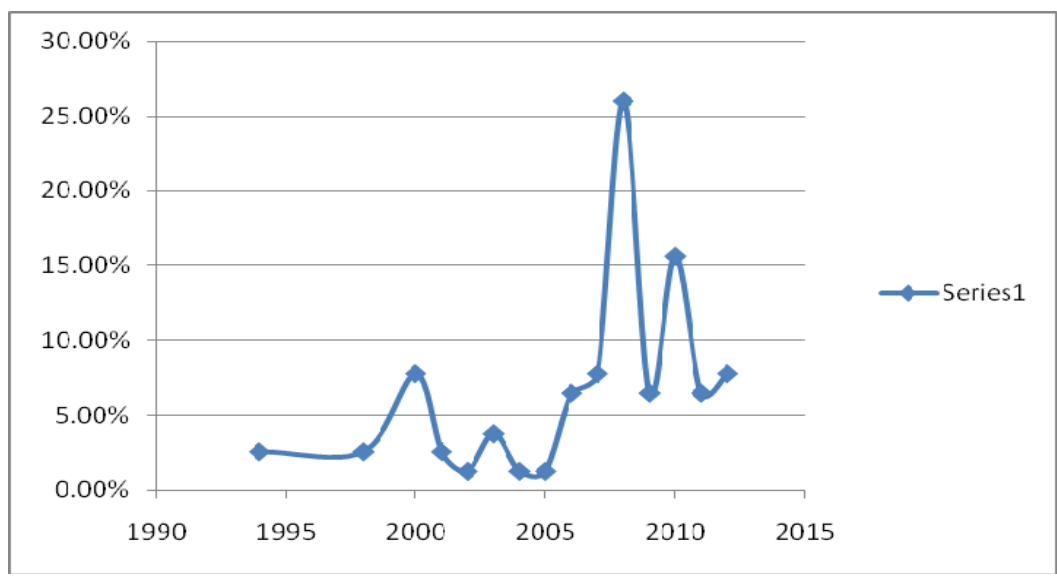

Figure 2. Years when businesses started operation

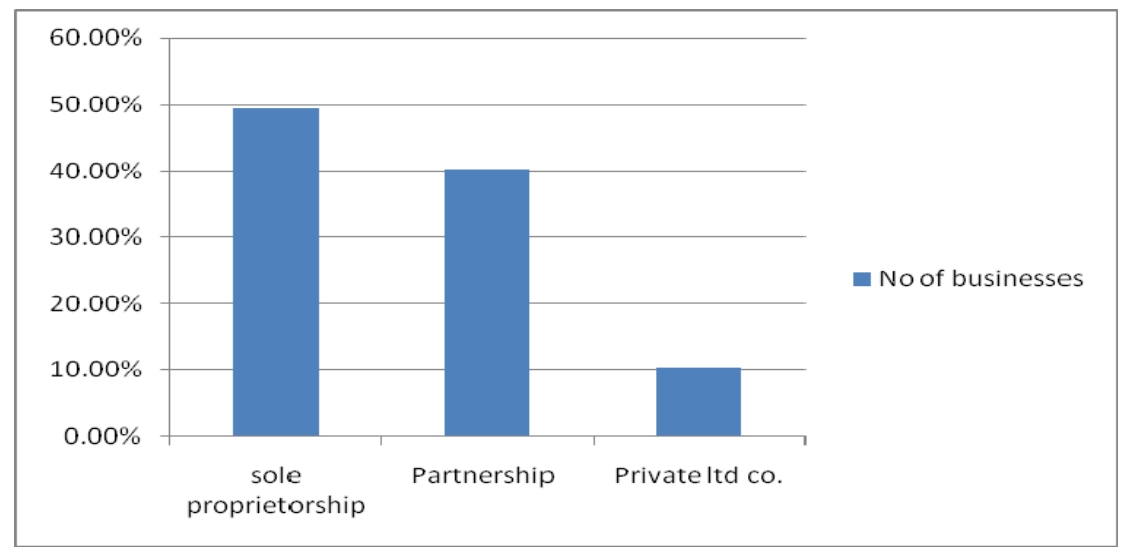

Figure 3. Type of business unit in operation

From the 77 respondents, 38 which represents $49.4 \%$ own sole proprietorship businesses, 31 which represents $40.2 \%$ have partnership and 8 which represents $10.4 \%$ have private limited companies.

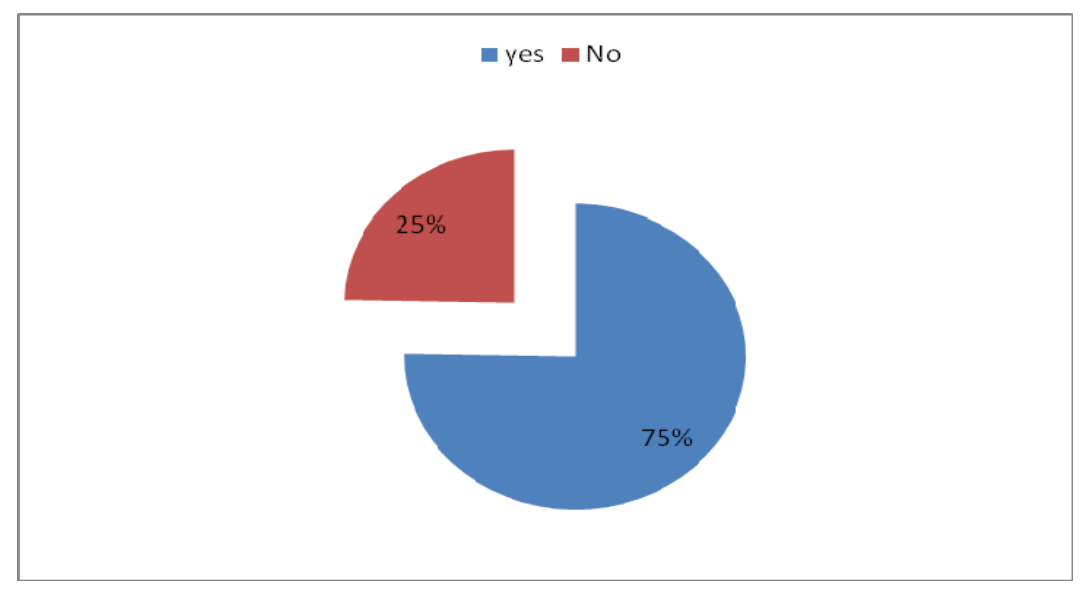

Figure 4. Monetary assistance by the bank

Findings revealed 58 respondents which represents $75.3 \%$ acknowledged having received monetary assistance from the Cooperative Bank and 19 which is $24.7 \%$ claimed the opposite. 
Table 1. Type of financial assistance received from the bank

\begin{tabular}{lll}
\hline Type of financial assistance & Number of customers & Percentage \\
\hline Msamaria women loans & 26 & $33.8 \%$ \\
Nguzo loans & 32 & $41.6 \%$ \\
Biashara & 10 & $13 \%$ \\
Others & 9 & $11.6 \%$ \\
\hline
\end{tabular}

Out of the 77 respondents, 26 which represents $33.8 \%$ said they have received Msamaria women loans, 32 which represents $41.6 \%$ said they have received Nguzo loans, 10 which is $13 \%$ have received Biashara plus loans and 9 which represents $11.6 \%$ said they have taken other loans.

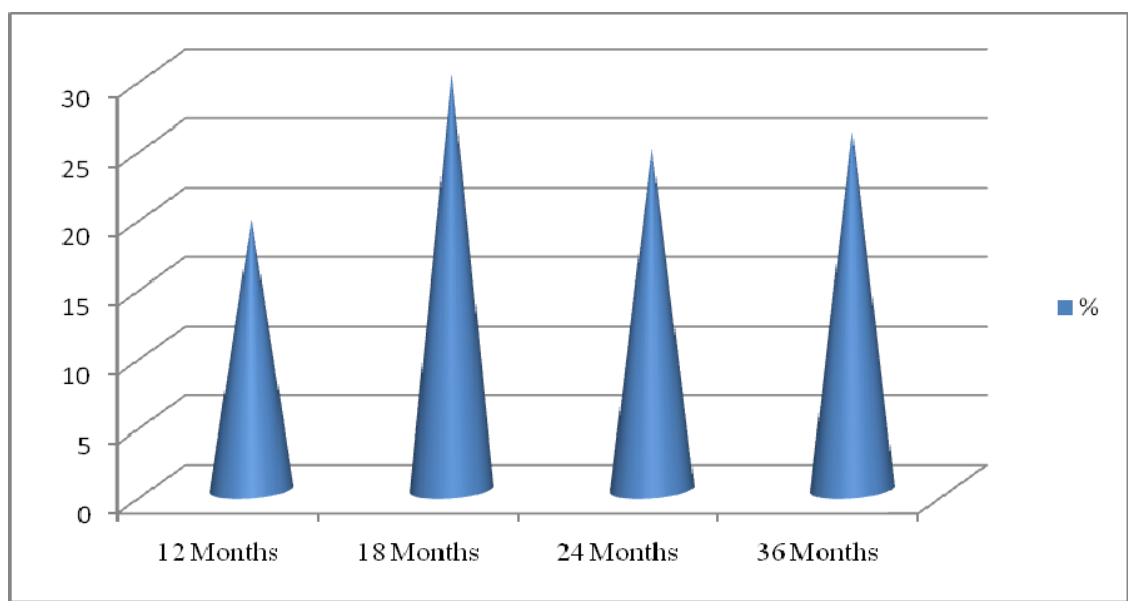

Figure 5. Repayment period

Findings reveal that 15 respondents which represents $19.5 \%$ reported that they have been given 12 months repayment period, 23 which is $30 \%$ reported 18 months, 19 which is $24.6 \%$ reported 24 months and 20 which represents $25.9 \%$ reported 36 months repayment period. The manager emphasized that Nguzo loans must be paid within 12 months and Msamaria between 12-36months.

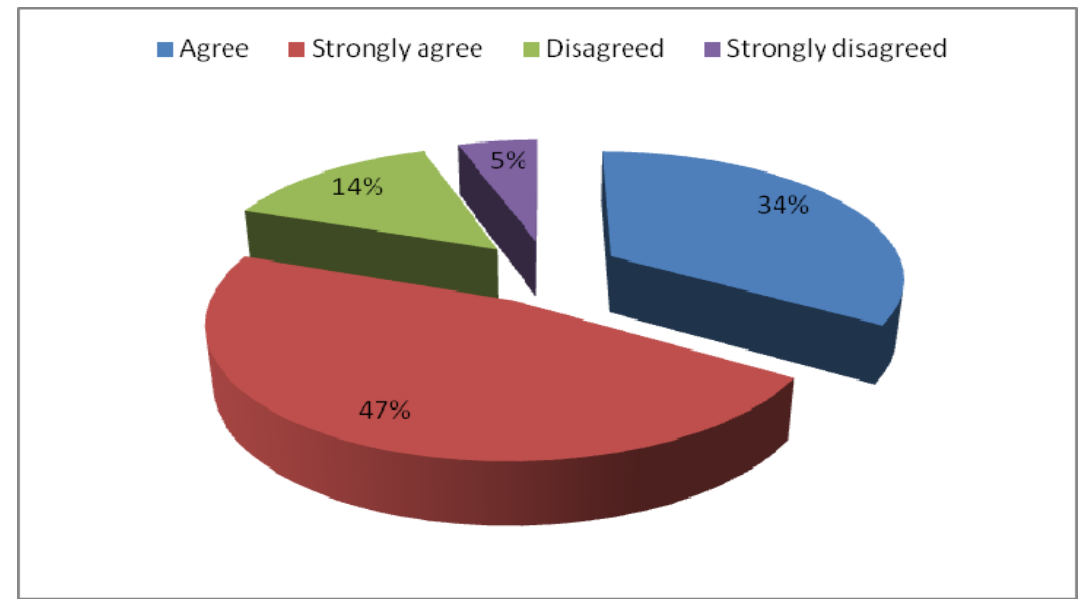

Figure 6. Acknowledgement of bank's financial help by women entrepreneurs

Out of 77 respondents, 36 which represents $47 \%$ strongly agreed that Cooperative bank is helping women entrepreneurs, 26 which represents $34 \%$ agreed, 11 which represents $14 \%$ and 4 which makes up $5 \%$ strongly disagreed. The branch manager said they have so far helped about 1000 small-micro businesses owned by women. 


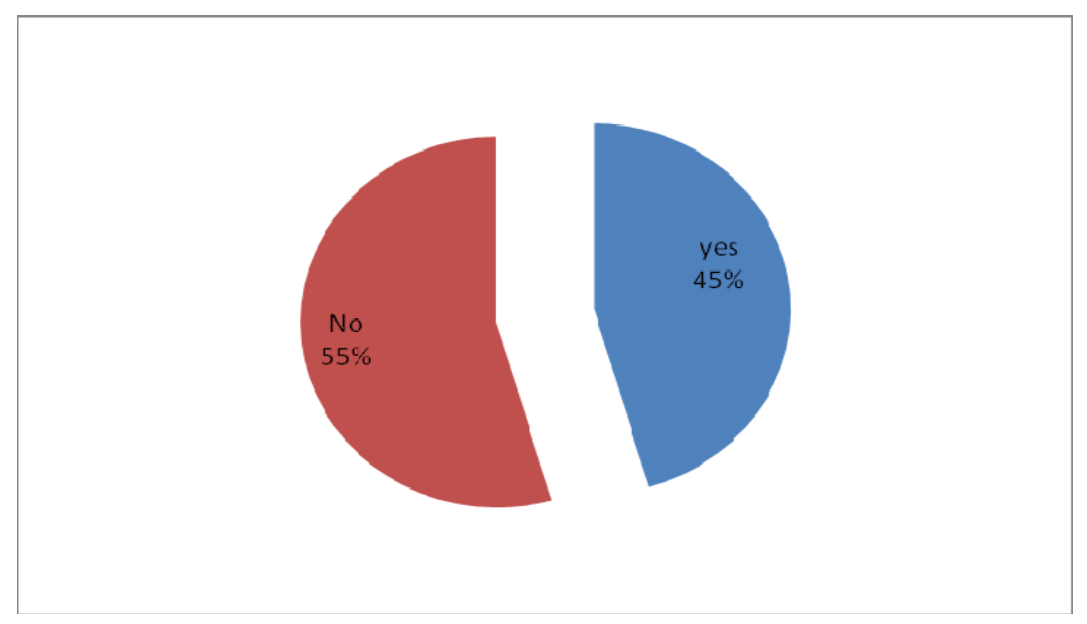

Figure 7. Additional assistance received from Cooperative Bank

35 respondents which represents $45.5 \%$ said they have received additional assistance from the bank while 42 which makes up 54.5\% said they have not received any other help from the bank. The manager clearly stated that products they offer to women are purely monetary and financial advise to some extent.

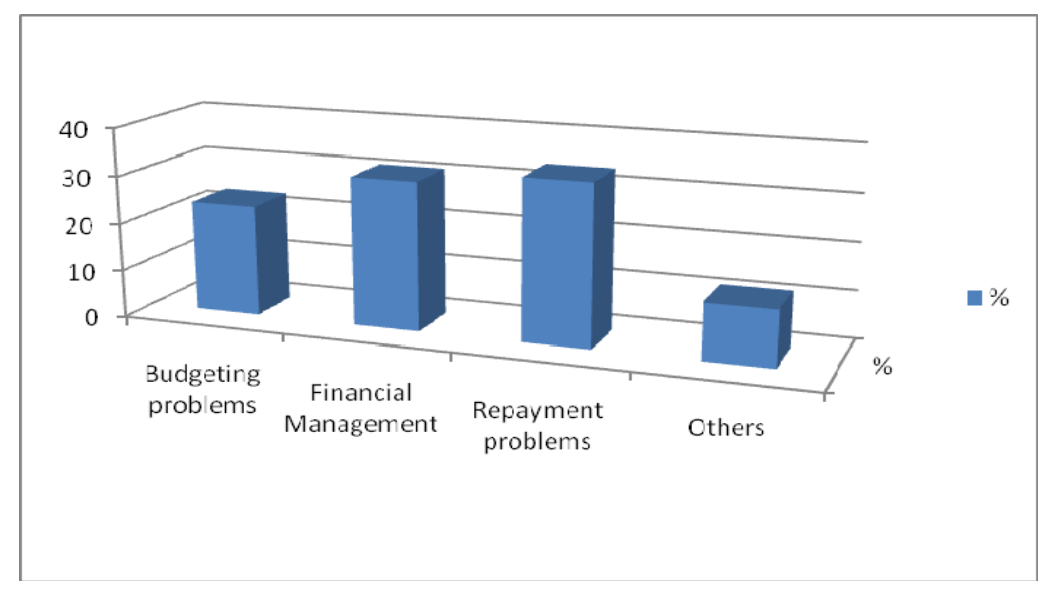

Figure 8. Challenges faced by the recepients of the finance from Cooperative Bank

18 respondents which represents $23.4 \%$ said they face budgeting problems, 25 which amounts to $31.2 \%$ faced financial management problem, 26 which amounts to $33,7 \%$ experienced repayment problems and 9 which is $11.7 \%$ experienced other problems such as dishonest partners and delayed payments. On the other hand the manager highlighted that the bank also faced challenges such as failed funded projects, diversion of funds, inability to follow up customers when a credit officers leaves the bank or are transferred. 
Table 2. Suggestions to improve Cooperative bank empowerment function

\begin{tabular}{|c|c|c|}
\hline Suggestions & $\begin{array}{l}\text { Number of } \\
\text { respondents }\end{array}$ & $\%$ \\
\hline $\begin{array}{l}\text { Train women entrepreneurs on } \\
\text { money matters }\end{array}$ & 26 & $33.8 \%$ \\
\hline Bank to improve customer service & 12 & $15.5 \%$ \\
\hline Reduce interest rate & 10 & $13 \%$ \\
\hline Increase payment period & 7 & $9.1 \%$ \\
\hline Closer bank supervision & 4 & $5.2 \%$ \\
\hline $\begin{array}{l}\text { Bank to give more support and } \\
\text { encouragement to women } \\
\text { entrepreneurs }\end{array}$ & 4 & $5.2 \%$ \\
\hline Mentors should conduct seminars & 3 & $3.9 \%$ \\
\hline $\begin{array}{l}\text { Advise on women entrepreneurs on } \\
\text { management of partnership }\end{array}$ & 2 & $2.6 \%$ \\
\hline $\begin{array}{l}\text { Offer discounts to women } \\
\text { entrepreneurs who bring in a new } \\
\text { customer }\end{array}$ & 2 & $2.6 \%$ \\
\hline Give loans in terms of assets & 2 & $2.6 \%$ \\
\hline Do away with interest rate & 1 & $1.3 \%$ \\
\hline Introduce grants & 1 & $1.3 \%$ \\
\hline $\begin{array}{l}\text { Benchmark with developed } \\
\text { countries }\end{array}$ & 1 & $1.3 \%$ \\
\hline $\begin{array}{l}\text { Bank should do aggressive } \\
\text { marketing }\end{array}$ & 1 & $1.3 \%$ \\
\hline $\begin{array}{l}\text { Bank should make loans to women } \\
\text { entrepreneurs more accessible }\end{array}$ & 1 & $1.3 \%$ \\
\hline
\end{tabular}

From the 77 respondents 26 which represents $33.8 \%$ suggested that women entrepreneurs should be trained on money matters, $15.5 \%$ felt the bank should improve its customer services, $13 \%$ suggested reduction of interest rate, $9.1 \%$ felt that the repayment period should be increased, 5.2\% suggested closer bank supervision, another 5.2\% felt the bank should give more support and encouragement to women entrepreneurs, $3.9 \%$ felt business mentors should conduct seminars, $2.6 \%$ felt women should be given advise on business matters especially management of partnership, another $2.6 \%$ felt that the bank should give discounts to women who bring another customer to the bank still another $2.6 \%$ felt loans should be given in form of assets rather than money, $1.3 \%$ felt the bank should do away with interest, another similar percentage suggested that the bank should introduce grants, still another $1.3 \%$ felt the bank should benchmark with developed countries, another similar percentage said the bank should engage aggressive marketing and another $1.3 \%$ felt that the bank should make loans to women entrepreneurs more accessible.

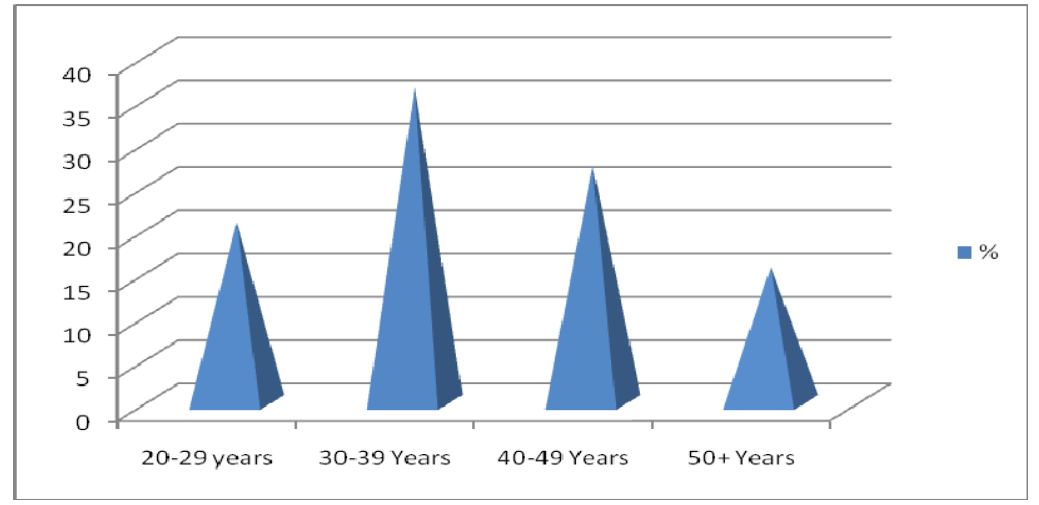

Figure 9. Women entrepreneurs age range

Findings show that 16 respondents which represents $20.7 \%$ fall between $20-29$ years, 28 which amounts to $36.4 \%$ fall between $30-39$ years, 21 which is $27.3 \%$ fall between ages $40-49$ and 12 which represents $15.6 \%$ fall between the range of $50+$ years. 


\subsection{Questionnaire}

Please help fill up this questionnaire, the survey has the objective to establish the role of Cooperative bank in empowering women entrepreneurs in Small and Micro enterprises (SMEs) in Kenya. The information collected here will solely be used for this survey only and nothing else.

1. What type of a business are you operating?
i) Food services
ii) Hair saloon
iii) Transport
iv) Others

2. When did you start your business? Year

3. In what business unit does your business fall?
i) Sole proprietorship
ii) Partnership
iii) Private limited company

4. Have you received any monetary assistance from the cooperative bank?

Yes

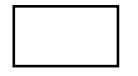

No

5. Referring to Question 4, which financial assistance did you receive from cooperative bank

i) Msamaria Women loans

ii) Nguzo loans

iii) Biashara Plus loans

iv) Others

6. How long is your repayment period?
i) 12 months
ii) 18 months
iii) 24 months
iv) 36 months

7. In your opinion, do you feel this financial assistance has helped your business?
i) Agree
ii) Strongly agree
iii) Disagree
iv) Strongly disagree

8. Apart from the financial assistance, have you received any other business assistance from Cooperative Bank in terms of training, mentoring or others?

Yes
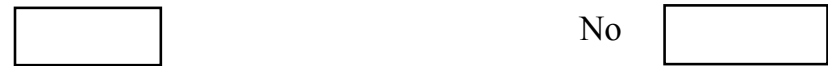

9. What challenges do you experience with this financial assistance from Cooperative bank?

i) Budgeting problems

ii) Financial management problems

iii) Inability to repay the loan

iv) Others

10. What would you like to see done differently by the cooperative bank as far as financial assistance to women is 
concerned

11. Your age range
i) 20- 29 years
ii) 30- 39 years
iii) 40- 49 years
iv) 50 - above years

\section{Thank you for your time}

\subsection{Interview Schedule}

1) How many products do you have for SMEs women entrepreneurs in Kenya?

2) Referring to $\mathrm{Q} 1$ please name the products

3) Are the products monetary or non-monetary?

4) When did the bank start offering such products?

5) Approximately how many women entrepreneurs has the bank assisted so far?

6) What is the amount offered by each product?

7) What are the requirements before an entrepreneur qualifies?

8) How long is the repayment period?

9) How does the bank follow up the repayment

10) Does the bank have defaulters?

11) Does the bank have systems in place to monitor the financed projects?

12) What challenges is the bank facing in such endeavors?

13) What can the bank recommend for future? 